\title{
Concentration of soybean isoflavones by nanofiltration and the effects of thermal treatments on the concentrate
}

\author{
Silvia Benedetti ${ }^{\text {a }}$, Elane Schwinden Prudêncio ${ }^{\text {b,* }}$, José Marcos Gontijo Mandarino ${ }^{\text {, }}$, \\ Katia Rezzadori ${ }^{a}$, José Carlos Cunha Petrus ${ }^{a}$ \\ a Departamento de Engenharia Química e Engenharia de Alimentos, Centro Tecnológico, Universidade Federal de Santa Catarina, Trindade, 88040-970, Florianópolis, SC, Brazil

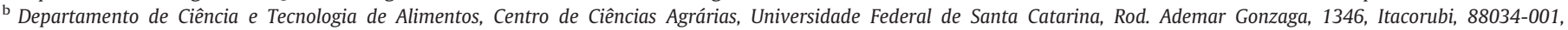 \\ Florianópolis, SC, Brazil

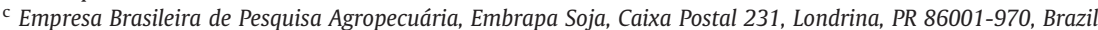

\section{A R T I C L E I N F O}

\section{Article history:}

Received 6 December 2010

Accepted 16 April 2011

\section{Keywords:}

Soybean

Isoflavones

Nanofiltration

Concentrate

Thermal treatment

\begin{abstract}
A B S T R A C T
An investigation was performed on the profile and the content of isoflavones in the concentrate of aqueous Defatted Soy Flour (DSF) extract obtained by nanofiltration. The effect of thermal treatments on these isoflavones was also evaluated according to a Central Composite Design $\left(\mathrm{CCD} 2^{\mathrm{k}}\right)$ with varying temperatures ( 70 to $90^{\circ} \mathrm{C}$ ) and times ( 15 to $45 \mathrm{~min}$ ). Through nanofiltration it was possible to concentrate $\beta$-glucosides and malonyl glucosides $(p<0.05)$ in aqueous DSF extract but it was not possible to concentrate aglycones $(p>0.05)$. The thermal treatments applied on the concentrate showed that the malonyl glucosides were influenced by temperature $(p<0.05)$, while the $\beta$-glucosides were influenced not only by temperature but also by the time of interaction of the factors investigated $(p<0.05)$. Moreover, there was no alteration in the contents $(p>0.05)$ of aglycone or total isoflavones.
\end{abstract}

(c) 2011 Elsevier Ltd. All rights reserved.

\section{Introduction}

Membrane separation processes such as nanofiltration (NF) have been investigated in relation to the concentration of bioactive compounds present in aqueous vegetal extracts (Cassini, Tessaro, Marczak, \& Pertile, 2010). One of the reasons for employing these processes is the low temperatures involved, in contrast to most conventional concentration procedures such as evaporation. The use of low temperature is important to maintain the functional properties of bioactive compounds like the isoflavones present in soybeans (GóesFavoni, Beléia, Carrão-Panizzi, \& Mandarino, 2004). Furthermore, NF is an attractive alternative method of concentration since it does not require the use of organic solvents, which are generally used in the extraction of these compounds (Mello, Petrus, \& Hubinger, 2010; Xu, Lamb, Layton, \& Kumar, 2004). However, NF requires the use of solutions with low lipid contents. According to Saboya and Maubois (2000) and Cuartas-Uribe, Alcaina-Miranda, Soriano-Costa, and Bespia (2007), fat globules tend to accumulate on the membrane surface, thus forming a gel layer, decreasing the permeate flux and resulting in the fouling of the membrane. The importance of removing lipids from the

\footnotetext{
* Corresponding author. Tel.: + 5548 37215366; fax: +55 4837219943. E-mail address: elane@cca.ufsc.br (E.S. Prudêncio).
}

feed was noted by Noordman, Kooiker, Bel, Dekker, and Wesselingh (2003) in the concentration of functional compounds obtained from an aqueous soy flour extract.

Isoflavones are phytoestrogens (Adlercreutz \& Mazur, 1997; GóesFavoni, Carrão-Panizzi, \& Beléia, 2010; Lee \& Lee, 2009; Ríaz, 1999) that present the following chemical forms: malonyl glucosides (malonyl genistin, malonyl daidzin and malonyl glycitin); $\beta$-glucosides (genistin, daidzin and glycitin); acetyl glucosides (acetyl genistin, acetyl daidzin and acetyl glycitin); and aglycones (genistein, daidzein and glycitein) (Genovese, Barbosa, Pinto, \& Lajolo, 2007; Ranilla, Genovese, \& Lajolo, 2009). These forms have been widely investigated for their beneficial effects on human health (Adlercreutz \& Mazur, 1997; Barnes et al., 2006; Chang, 2002). Variations in soybean processing influence the profiles and contents of isoflavones. Wang and Murphy (1994) reported that $98 \%$ of the isoflavones in soybeans or in soy products occur as $\beta$-glucosides, acetyl glucosides and malonyl glucosides, whereas Barnes, Coward, Kirk, and Sfakianos (1998) state that there is a predominance of conjugated forms such as malonyl, which can be converted into acetyl and $\beta$-glucosides during thermal treatment. Fukutake et al. (1996) and Sutil et al. (2008) noted that larger amounts of aglycones are formed at around $50{ }^{\circ} \mathrm{C}$.

According to Eisen, Ungar, and Shimoni (2003), Huang, Liang, and Kwok (2006) and Nufer, Ismail, and Hayes (2009), it is very important to note the transformations and the degradation of isoflavones in the concentrate submitted to different thermal treatments. Thus, the objective of this study was to concentrate the soybean isoflavones of the aqueous extract of DSF by nanofiltration, to evaluate the profile 
and the contents of these compounds in the concentrate and to investigate the influence of different thermal treatments.

\section{Material and methods}

\subsection{Material}

Genetically enhanced soybeans of the cultivar BRS 216, which have high protein and isoflavone contents (Carrão-Panizzi et al., 2001) were supplied by Empresa Brasileira de Pesquisa Agropecuária - Centro Nacional de Pesquisa da Soja (Embrapa Soja). The isoflavones were identified and quantified through comparison with the standard curves for daidzin, daidzein (Fujicco Co., Ltd, Tokyo, Japan), genistin, genistein (Sigma Chemicals Co., Ltd, St. Louis, MO, USA.), glycitin, glycitein, malonyl daidzin, malonyl genistin, malonyl glicitin, acetyl daidzin, acetyl genistin and acetyl glycitin (Wako Chemicals, Anaheim, CA, USA). All reagents were of analytical or chromatographic grade.

\subsection{Preparation of the aqueous defatted soy flour (DSF) extract}

To prepare the aqueous DSF extract, the soybeans were dried in a forced air oven (Model 320-SE, FANEM ${ }^{\circledR}$, São Paulo, Brazil) at $40{ }^{\circ} \mathrm{C}$ for $24 \mathrm{~h}$. After drying, the soybeans were milled in a knife mill (VIBRAMATT ${ }^{\circ}$, São Paulo, SP, Brazil). The flour obtained in this stage was first sieved through a 20-mesh and then a 35-mesh stainless screen (GRANUTEST ${ }^{\circledR}$, São Paulo, Brazil) and defatted with n-hexane at ambient temperature (around $25^{\circ} \mathrm{C}$ ). The DSF was mixed with water at a ratio of $1: 8$ (DSF:water), stored at $50{ }^{\circ} \mathrm{C}$ and stirred with an orbital shaker (Model TE-421, TECNAL®, Piracicaba, SP, Brazil) for $15 \mathrm{~h}$. This stage is necessary for the aglycone formation. Additional stirring was performed at room temperature $\left(25^{\circ} \mathrm{C}\right)$ for $5 \mathrm{~min}$ with a magnetic shaker (Model Q-261, QUIMIS ${ }^{\circledR}$, Diadema, SP, Brazil). This mixture underwent two stages of filtration; the first stage was carried out with a nylon filter (80 mesh) (BRASHOLANDA®, Pinhais, PR, Brazil) to remove the larger particles of flour and the second stage was performed using a vacuum filter made of polyamide with a pore size of $7 \mu \mathrm{m}$ (TEGAPE $®$, Curitiba, PR Brazil), thus obtaining the aqueous DSF extract.

\subsection{Nanofiltration (NF)}

The aqueous DSF extract was concentrated through nanofiltration using a tangential flow filtration pilot plant equipped with a poly-viny-lidene difluoride (PVDF) filter in the spiral configuration with molecular weight cut-off (MWCO) ranging between 150 and $300 \mathrm{~g} \mathrm{~mol}^{-1}$ and effective filter area of $0.9 \mathrm{~m}^{2}$ (GE Osmonics ${ }^{\circledR}$, Philadelphia, USA). The experiments were carried out in duplicate at $16 \pm 2{ }^{\circ} \mathrm{C}$ and with a transmembrane pressure of 7 bar until reaching a volume reduction factor (VRF) of 4 . The VRF was calculated as the ratio between the initial volume (L) of the aqueous DSF extract used in the feed and the final volume (L) of the concentrate after NF. The permeate flux (J) $\left(\mathrm{L} \mathrm{h}^{-1} \mathrm{~m}^{-2}\right)$ during NF can be calculated as follows:

$\mathrm{J}=\frac{\mathrm{V}_{\mathrm{p}}}{\mathrm{t} \times \mathrm{A}_{\mathrm{p}}}$

where $V_{p}(\mathrm{~L})$ is the amount of permeate collected during the period of time $t(\mathrm{~h})$ and $A_{p}\left(\mathrm{~m}^{2}\right)$ is the permeation surface area of the membrane. The quality of the filtration process was measured based on the isoflavone content present in the concentrate. After each experiment, the equipment was cleaned with alkaline solution $(0.1 \%)$ according to manufacturer's instructions.

\subsection{Experimental design for the thermal treatment of the concentrate}

In this study, a Central Composite Design (CCD $\left.2^{\mathrm{k}}\right)$ was used to perform the thermal treatment of the concentrate at VRF 4 . The independent variables temperature $\mathrm{X}_{1}\left({ }^{\circ} \mathrm{C}\right)$ and time $\mathrm{X}_{2}$ (minutes) were analyzed at the three equidistant levels of variation, encoded as $-1,0$, and +1 . The experimental design consisted of 11 assays; four factorial (combination of levels -1 and +1 ), four axial (one variable at the level $\pm \alpha$ and another one at zero) and three repetitions at the central point (two variables at level zero) (Table 1). Experiments in the center of the design were performed to estimate possible pure errors. Because of systematic errors, all the experiments were carried out at random to minimize the effect of unexplained variability on the responses observed. The dependent variable (response) was the total isoflavone content $\left(\mu \mathrm{g} \mathrm{mL}{ }^{-1}\right)$.

The levels of the variables and the central point were defined based on data available in the literature on the thermal treatment of soybean products. Some authors (Chien, Hsieh, Kao, \& Chen, 2005; Grün et al., 2001; Huang et al., 2006; Toda, Sakamoto, Takayanagi, \& Yokotsuka, 2000) have used temperatures of between 70 and $90{ }^{\circ} \mathrm{C}$ to evaluate the profile of isoflavones and their kinetic degradation.

\subsection{Thermal treatments of the concentrate}

The thermal treatments were applied to the concentrate of the aqueous DSF extract in $5 \mathrm{~mL}$ glass tubes with $0.9 \mathrm{~mm}$ wall thickness, $10 \mathrm{~mm}$ internal diameter, and $11 \mathrm{~cm}$ in length. These tubes, which contained samples of the concentrate, were closed and then immersed in a thermostated bath (Model Q215M, CALLMEX®, Florianopolis, SC, Brazil) at the temperature of the assay. The temperature was monitored with a thermometer (INCOTERM $®$, Porto Alegre, RS, Brazil). The experimental design was composed of 11 assays. The thermal treatments were performed for each assay in the experimental design. At the end of each assay, the tubes were immediately immersed in an ice bath to cool the samples. After the thermal treatments, the concentrates were placed into clear conical polypropylene centrifugation tubes (Falcon ${ }^{\circledR}$ ) with $50 \mathrm{~mL}$ of volume and screw caps with dimensions of $30 \mathrm{~mm}$ O.D and $115 \mathrm{~mm}$ length. They were then frozen and stored at $-18{ }^{\circ} \mathrm{C}$ for one week until the determination of isoflavones through high-performance liquid chromatography (HPLC).

\subsection{Isoflavone extraction and determination}

The extraction of isoflavones and the determination of their components were carried out with samples of the DSF, of the aqueous DSF extract, and of the concentrate before and after thermal treatments,

Table 1

Central Composite Design (CCD) with codified and reals values for two independent variables.

\begin{tabular}{|c|c|c|c|c|}
\hline \multirow[t]{2}{*}{ Assay } & \multicolumn{2}{|c|}{ Codified } & \multicolumn{2}{|l|}{ Reals } \\
\hline & $\mathrm{X}_{1}^{\mathrm{a}}$ & $\mathrm{X}_{2}^{\mathrm{b}}$ & Temperature $\left({ }^{\circ} \mathrm{C}\right)$ & Time (minutes) \\
\hline 1 & -1 & -1 & 70 & 15 \\
\hline 2 & +1 & -1 & 90 & 15 \\
\hline 3 & -1 & +1 & 70 & 45 \\
\hline 4 & +1 & +1 & 90 & 45 \\
\hline 5 & $-\alpha^{\mathrm{c}}$ & 0 & 66 & 30 \\
\hline 6 & $+\alpha$ & 0 & 94 & 30 \\
\hline 7 & 0 & $-\alpha$ & 80 & 9 \\
\hline 8 & 0 & $+\alpha$ & 80 & 51 \\
\hline 9 & 0 & 0 & 80 & 30 \\
\hline 10 & 0 & 0 & 80 & 30 \\
\hline 11 & 0 & 0 & 80 & 30 \\
\hline
\end{tabular}

${ }^{a} \mathrm{X}_{1}=$ temperature variable.

b $\mathrm{X}_{2}=$ time of thermal treatment variable.

c $\alpha= \pm 1.414$ for two independent variables. 


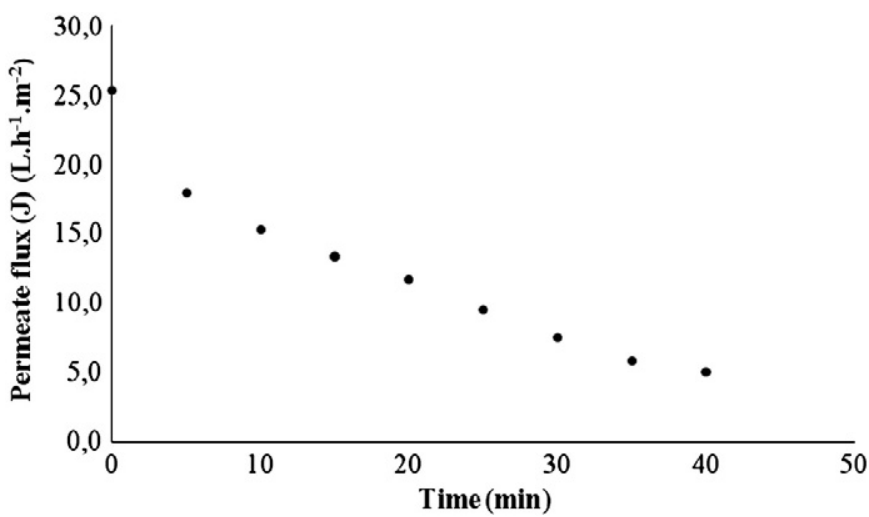

Fig. 1. Permeate flux (J) during nanofiltration process of aqueous extract of defatted soy flour.

according to the methodology proposed by Carrão-Panizzi, Favoni, and Kikuchi (2002) with modifications. To extract isoflavones from the DSF, $100 \mathrm{mg}$ of sample was transferred to a $10 \mathrm{~mL}$ test tube, into which $4 \mathrm{~mL}$ of an extracting solution (70\% ethanol and $0.1 \%$ acetic acid) were added. To extract isoflavones from the aqueous DSF extract and from the concentrate, an aliquot of $1.5 \mathrm{~mL}$ of sample was used. This aliquot of sample was added to $2.5 \mathrm{~mL}$ of the same extracting solution as that of the isoflavone extraction from the DSF. The test tubes with the samples and the extracting solution were stirred in a Vortex (Model MA162, MARCONI ${ }^{\circledR}$, Piracicaba, SP, Brazil) and submitted to extraction for $1 \mathrm{~h}$ at ambient temperature $\left(25^{\circ} \mathrm{C}\right)$ with stirring every $15 \mathrm{~min}$. The test tubes were then placed into an ultrasound bath (Model USC5000, UNIQUE®, Indaiatuba, SP, Brazil) and left for $30 \mathrm{~min}$. A $1.5 \mathrm{~mL}$ aliquot of this extract was transferred to a refrigerated microcentrifuge (dimensions of $31 \times 60 \times 25 \mathrm{~cm}, 35 \mathrm{~kg}$, Model 5417R $230 \mathrm{~V} / 50 \mathrm{~Hz}$, EPENDORFF®, São Paulo, Brazil) and centrifuged at $20,800 \mathrm{~g}$ for $15 \mathrm{~min}$ at $5{ }^{\circ} \mathrm{C}$. The supernatant was filtered through $0.45 \mu \mathrm{m}$ filters (MILLIPORE ${ }^{\circledR}$, Billerica, MA, USA) and $20 \mu \mathrm{L}$ was used to separate and quantify the isoflavones through chromatography.

The separation and the quantification of the isoflavones were performed using HPLC, as proposed by Berhow (2002), with a photodiode array detector (Model 996) and an automatic sample injector (Model 717 Plus), both manufactured by WATERS® (Milford, USA). In this stage, a reverse phase column (YMC-Pack ODS-AM, C18, $\mathrm{S}-5 \mu \mathrm{m}$, diameter of $250 \times 4.6 \mathrm{~mm}$ ) was used. For the separation of isoflavones, the binary linear gradient system was used and the mobile phases were: (a) methanol containing $0.025 \%$ trifluoroacetic acid (TFA) (Phase A) and (b) ultrapure water (MILLIPORE®, Billerica, MA, USA) containing $0.025 \%$ TFA (Phase B). The initial condition of the gradient was $20 \%$ in Phase A, reaching $90 \%$ in 35 min, followed by cleaning of the column with $100 \%$ of Phase A for 5 min and subsequently return to $20 \%$, retaining these conditions for up to $60 \mathrm{~min}$. The mobile phase flow was of $1 \mathrm{~mL} \mathrm{~min}{ }^{-1}$ and the temperature during the analysis was $25^{\circ} \mathrm{C}$. For the isoflavone detection, the wavelength of the detector was adjusted to $254 \mathrm{~nm}$. The software used to control the equipment and the data acquisition was Millennium 32 (version 3.05.01) (GCLC® Toronto, Pickering, ON, Canada). For the identification and quantification of the peaks corresponding to each one of the isoflavones, calibration curves with linear regression based on the peak areas were used. These calibration curves were constructed with external standards of daidzin, daidzein, genistin, genistein, glycitin, glycitein, malonyl daidzin, malonyl genistin, malonyl glicitin, acetyl daidzin, acetyl genistin and acetyl glycitin, all of which were solubilized in methanol (chromatographic grade) to the following concentrations: $0.00625 \mathrm{mg} \mathrm{mL}^{-1} ; 0.0125 \mathrm{mg} \mathrm{mL}^{-1}$; $0.0250 \mathrm{mg} \mathrm{mL}^{-1} ; 0.0500 \mathrm{mg} \mathrm{mL}^{-1}$ and $0.1000 \mathrm{mg} \mathrm{mL}^{-1}$. The results for the DSF isoflavone content were expressed as mg of isoflavones per $100 \mathrm{~g}$ of solid sample and the extracts were expressed as $\mu \mathrm{g}$ of isoflavones per $g$ of extract on dry basis. All these analyses were performed in duplicate.

\subsection{Statistical analysis}

The data were expressed as means and standard deviation. Analysis of variance (ANOVA) and Tukey's studentized range test (5\% significance) were carried out to detect any significant differences. The regression coefficients for the linear, quadratic, and interaction terms were determined through multiple linear regression. The significance of each regression coefficient was determined statistically by computing the t-value from the pure error obtained from the replicates at the central point of this experiment. ANOVA was used to validate the model. The regression coefficients were then used to generate response surfaces. The software Statistica 7.0 (2004) (StatSotft Inc., Tulsa, OK, USA) was used to perform all calculations and obtain all of the graphs.

\section{Results and discussion}

\subsection{Nanofiltration (NF)}

The behavior of the permeate flux (J) during the NF of the aqueous DSF extract is shown in Fig. 1. Hodúr, Kertész, Beszédes, László, and Szabó (2009) noted a similar behavior in concentrations obtained from aqueous extracts of similar products using membranes. Noordman et al. (2003) and Habert, Borges, and Nóbrega (2006) state that liquid foods with high protein content tend to show such behavior. Moreover, this decrease in the J value can be attributed to the polarization layer,

Table 2

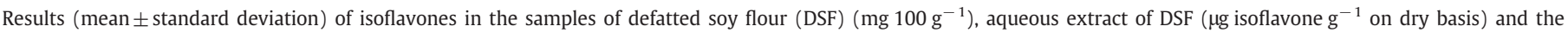
concentrate obtained from nanofiltration ( $\mu \mathrm{g}$ isoflavone $\mathrm{g}^{-1}$ on dry basis).

\begin{tabular}{|c|c|c|c|c|}
\hline Samples & & \multirow{2}{*}{$\begin{array}{l}\text { DSF } \\
\left(\mathrm{mg} 100 \mathrm{~g}^{-1}\right)\end{array}$} & \multirow{2}{*}{$\begin{array}{l}\text { Aqueous } \\
\text { extract of DSF } \\
\left(\mu \mathrm{g} \mathrm{g}^{-1} \text { d.b) }\right.\end{array}$} & \multirow{2}{*}{$\begin{array}{l}\text { Concentrate } \\
\left(\mu g g^{-1} \text { d.b) }\right.\end{array}$} \\
\hline Isoflavones & & & & \\
\hline \multirow[t]{3}{*}{ Malonyl glucosides } & Malonyl genistin & $97.53 \pm 0.84$ & $189.02^{\mathrm{b}} \pm 1.38$ & $385.21^{\mathrm{a}} \pm 33.88$ \\
\hline & Malonyl daidzin & $69.56 \pm 0.36$ & $363.90^{\mathrm{b}} \pm 5.31$ & $757.66^{\mathrm{a}} \pm 11.76$ \\
\hline & Malonyl glycitin & $3.59 \pm 0.29$ & $168.71^{\mathrm{b}} \pm 1.07$ & $350.25^{\mathrm{a}} \pm 15.90$ \\
\hline \multirow[t]{3}{*}{$\beta$-Glucosides } & Genistin & $67.92 \pm 0.60$ & $59.37^{\mathrm{b}} \pm 6.85$ & $108.94^{\mathrm{a}} \pm 24.03$ \\
\hline & Daidzin & $48.35 \pm 0.28$ & $76.90^{\mathrm{b}} \pm 1.24$ & $165.55^{\mathrm{a}} \pm 8.85$ \\
\hline & Glycitin & $3.07 \pm 0.04$ & $47.41^{b} \pm 1.81$ & $97.34^{\mathrm{a}} \pm 1.64$ \\
\hline \multirow[t]{3}{*}{$\mathrm{DSF}\left(\mathrm{mg} 100 \mathrm{~g}^{-1}\right)$} & Acetyl genistin & n.d. ${ }^{\mathrm{a}}$ & n.d. & n.d. \\
\hline & Acetyl daidzin & n.d. & n.d. & n.d. \\
\hline & Acetyl glycitin & n.d. & n.d. & n.d. \\
\hline \multirow[t]{3}{*}{$\mathrm{DSF}\left(\mathrm{mg} 100 \mathrm{~g}^{-1}\right)$} & Genistein & $3.13 \pm 0.04$ & $103.50^{\mathrm{a}} \pm 1.20$ & $120.40^{\mathrm{a}} \pm 32.31$ \\
\hline & Daidzein & $2.00 \pm 0.02$ & $195.85^{\mathrm{a}} \pm 1.94$ & $177.60^{\mathrm{a}} \pm 29.60$ \\
\hline & Glycitein & n.d. & $95.37^{\mathrm{a}} \pm 2.57$ & $89.05^{\mathrm{a}} \pm 14.57$ \\
\hline Total isoflavones & & $295.15 \pm 0.29$ & $1300.03^{\mathrm{a}} \pm 2.37$ & $2251.98^{\mathrm{b}} \pm 169.25$ \\
\hline
\end{tabular}

n.d. = not detected.

${ }^{a, b}$ Different letters in the same line indicate significant differences between samples $(p<0.05)$. 
Table 3

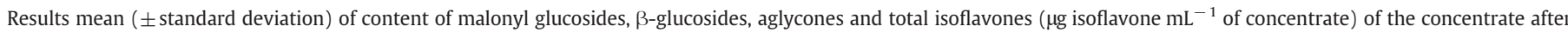
thermal treatments.

\begin{tabular}{|c|c|c|c|c|c|c|c|c|c|c|c|c|c|}
\hline \multirow[t]{2}{*}{ Assays } & \multicolumn{4}{|c|}{ Malonyl glucosides $\left(\mu \mathrm{g} \mathrm{mL}^{-1}\right)$} & \multicolumn{4}{|c|}{$\beta$-Glucosides $\left(\mu \mathrm{g} \mathrm{mL}^{-1}\right)$} & \multicolumn{4}{|c|}{ Aglycones $\left(\mu \mathrm{g} \mathrm{mL}^{-1}\right)$} & \multirow{2}{*}{$\begin{array}{l}\text { Total } \\
\text { isoflavones } \\
\left(\mu \mathrm{gL}^{-1}\right)\end{array}$} \\
\hline & Malonyl daidzin & Malonyl genistin & Malonyl glycitin & Total $^{\mathrm{a}}$ & Daidzin & Genistin & Glycitin & Total $^{\mathrm{b}}$ & Daidzein & Genistein & Glycitein & Total $^{\mathrm{c}}$ & \\
\hline 1 & $\begin{array}{l}63.06 \\
( \pm 3.17)\end{array}$ & $\begin{array}{l}33.20 \\
( \pm 0.95)\end{array}$ & $\begin{array}{l}28.36 \\
( \pm 1.24)\end{array}$ & $\begin{array}{l}12462 \\
( \pm 5.36)\end{array}$ & $\begin{array}{l}8.56 \\
( \pm 0.04)\end{array}$ & $\begin{array}{l}7.12 \\
( \pm 0.27)\end{array}$ & $\begin{array}{l}4.52 \\
( \pm 0.02)\end{array}$ & $\begin{array}{l}20.20 \\
( \pm 0.33)\end{array}$ & $\begin{array}{l}16.77 \\
( \pm 0.21)\end{array}$ & $\begin{array}{l}13.12 \\
( \pm 0.10)\end{array}$ & $\begin{array}{l}7.34 \\
( \pm 0.09)\end{array}$ & $\begin{array}{l}37.23 \\
( \pm 0.40)\end{array}$ & $\begin{array}{l}182.04 \\
( \pm 6.09)\end{array}$ \\
\hline 2 & $\begin{array}{l}60.89 \\
( \pm 0.58)\end{array}$ & $\begin{array}{l}31.53 \\
( \pm 0.44)\end{array}$ & $\begin{array}{l}27.76 \\
( \pm 0.21)\end{array}$ & $\begin{array}{l}120.18 \\
( \pm 0.81)\end{array}$ & $\begin{array}{l}12.45 \\
( \pm 0.17)\end{array}$ & $\begin{array}{l}9.20 \\
( \pm 0.02)\end{array}$ & $\begin{array}{l}5.46 \\
( \pm 0.18)\end{array}$ & $\begin{array}{l}27.12 \\
( \pm 0.01)\end{array}$ & $\begin{array}{l}17.06 \\
( \pm 0.18)\end{array}$ & $\begin{array}{l}13.42 \\
( \pm 0.02)\end{array}$ & $\begin{array}{l}7.29 \\
( \pm 0.04)\end{array}$ & $\begin{array}{l}3777 \\
( \pm 0.23)\end{array}$ & $\begin{array}{l}185.07 \\
( \pm 1.05)\end{array}$ \\
\hline 3 & $\begin{array}{l}64.13 \\
( \pm 0.09)\end{array}$ & $\begin{array}{l}33.16 \\
( \pm 0.22)\end{array}$ & $\begin{array}{l}29.20 \\
( \pm 0.31)\end{array}$ & $\begin{array}{l}126.49 \\
( \pm 0.01)\end{array}$ & $\begin{array}{l}9.85 \\
( \pm 5.36)\end{array}$ & $\begin{array}{l}7.82 \\
( \pm 0.16)\end{array}$ & $\begin{array}{l}5.22 \\
( \pm 0.53)\end{array}$ & $\begin{array}{l}22.89 \\
( \pm 1.16)\end{array}$ & $\begin{array}{l}17.44 \\
( \pm 0.27)\end{array}$ & $\begin{array}{l}14.19 \\
( \pm 0.24)\end{array}$ & $\begin{array}{l}7.76 \\
( \pm 0.19)\end{array}$ & $\begin{array}{l}39.39 \\
( \pm 0.70)\end{array}$ & $\begin{array}{l}188.77 \\
( \pm 1.85)\end{array}$ \\
\hline 4 & $\begin{array}{l}49.36 \\
( \pm 2.34)\end{array}$ & $\begin{array}{l}23.16 \\
( \pm 0.93)\end{array}$ & $\begin{array}{l}25.98 \\
( \pm 0.13)\end{array}$ & $\begin{array}{l}98.49 \\
( \pm 3.14)\end{array}$ & $\begin{array}{l}18.77 \\
( \pm 5.36)\end{array}$ & $\begin{array}{l}13.66 \\
( \pm 0.01)\end{array}$ & $\begin{array}{l}6.71 \\
( \pm 0.82)\end{array}$ & $\begin{array}{l}39.14 \\
( \pm 0.77)\end{array}$ & $\begin{array}{l}17.32 \\
( \pm 0.41)\end{array}$ & $\begin{array}{l}13.75 \\
( \pm 0.07)\end{array}$ & $\begin{array}{l}7.18 \\
( \pm 0.91)\end{array}$ & $\begin{array}{l}38.26 \\
( \pm 0.57)\end{array}$ & $\begin{array}{l}175.89 \\
( \pm 4.49)\end{array}$ \\
\hline 5 & $\begin{array}{l}56.92 \\
( \pm 9.40)\end{array}$ & $\begin{array}{l}27.88 \\
( \pm 7.13)\end{array}$ & $\begin{array}{l}27.35 \\
( \pm 1.23)\end{array}$ & $\begin{array}{l}112.16 \\
( \pm 15.32)\end{array}$ & $\begin{array}{l}8.40 \\
( \pm 5.36)\end{array}$ & $\begin{array}{l}6.72 \\
( \pm 1.09)\end{array}$ & $\begin{array}{l}4.51 \\
( \pm 0.29)\end{array}$ & $\begin{array}{l}19.63 \\
( \pm 1.86)\end{array}$ & $\begin{array}{l}15.28 \\
( \pm 1.61)\end{array}$ & $\begin{array}{l}12.37 \\
( \pm 1.63)\end{array}$ & $\begin{array}{l}7.17 \\
( \pm 0.55)\end{array}$ & $\begin{array}{l}34.81 \\
( \pm 3.80)\end{array}$ & $\begin{array}{l}166.60 \\
( \pm 17.25)\end{array}$ \\
\hline 6 & $\begin{array}{l}48.03 \\
( \pm 0.41)\end{array}$ & $\begin{array}{l}24.87 \\
( \pm 0.64)\end{array}$ & $\begin{array}{l}20.39 \\
( \pm 0.38)\end{array}$ & $\begin{array}{l}93.29 \\
( \pm 0.67)\end{array}$ & $\begin{array}{l}16.42 \\
( \pm 5.36)\end{array}$ & $\begin{array}{l}12.73 \\
( \pm 0.29)\end{array}$ & $\begin{array}{l}6.92 \\
( \pm 0.27)\end{array}$ & $\begin{array}{l}36.07 \\
( \pm 2.23)\end{array}$ & $\begin{array}{l}15.43 \\
( \pm 0.70)\end{array}$ & $\begin{array}{l}12.48 \\
( \pm 0.12)\end{array}$ & $\begin{array}{l}7.29 \\
( \pm 0.66)\end{array}$ & $\begin{array}{l}35.21 \\
( \pm 1.47)\end{array}$ & $\begin{array}{l}164.57 \\
( \pm 4.37)\end{array}$ \\
\hline 7 & $\begin{array}{l}62.33 \\
( \pm 0.20)\end{array}$ & $\begin{array}{l}33.17 \\
( \pm 0.06)\end{array}$ & $\begin{array}{l}27.05 \\
( \pm 1.91)\end{array}$ & $\begin{array}{l}122.55 \\
( \pm 1.76)\end{array}$ & $\begin{array}{l}9.79 \\
( \pm 5.36)\end{array}$ & $\begin{array}{l}6.96 \\
( \pm 0.12)\end{array}$ & $\begin{array}{l}5.00 \\
( \pm 0.23)\end{array}$ & $\begin{array}{l}21.74 \\
( \pm 2.87)\end{array}$ & $\begin{array}{l}15.99 \\
( \pm 0.07)\end{array}$ & $\begin{array}{l}12.88 \\
( \pm 0.06)\end{array}$ & $\begin{array}{l}7.46 \\
( \pm 0.06)\end{array}$ & $\begin{array}{l}36.33 \\
( \pm 0.06)\end{array}$ & $\begin{array}{l}180.62 \\
( \pm 4.70)\end{array}$ \\
\hline 8 & $\begin{array}{l}56.62 \\
( \pm 0.44)\end{array}$ & $\begin{array}{l}30.16 \\
( \pm 1.20)\end{array}$ & $\begin{array}{l}23.91 \\
( \pm 1.14)\end{array}$ & $\begin{array}{l}110.69 \\
( \pm 1.91)\end{array}$ & $\begin{array}{l}13.51 \\
( \pm 5.36)\end{array}$ & $\begin{array}{l}10.44 \\
( \pm 0.04)\end{array}$ & $\begin{array}{l}6.62 \\
( \pm 0.18)\end{array}$ & $\begin{array}{l}30.57 \\
( \pm 0.28)\end{array}$ & $\begin{array}{l}16.55 \\
( \pm 0.14)\end{array}$ & $\begin{array}{l}13.41 \\
( \pm 0.23)\end{array}$ & $\begin{array}{l}8.82 \\
( \pm 1.87)\end{array}$ & $\begin{array}{l}38.78 \\
( \pm 2.24)\end{array}$ & $\begin{array}{l}180.04 \\
( \pm 0.61)\end{array}$ \\
\hline 9 & $\begin{array}{l}61.14 \\
( \pm 5.79)\end{array}$ & $\begin{array}{l}30.20 \\
( \pm 0.50)\end{array}$ & $\begin{array}{l}29.19 \\
( \pm 3.98)\end{array}$ & $\begin{array}{l}120.52 \\
( \pm 9.27)\end{array}$ & $\begin{array}{l}10.89 \\
( \pm 5.36)\end{array}$ & $\begin{array}{l}9.00 \\
( \pm 0.03)\end{array}$ & $\begin{array}{l}5.25 \\
( \pm 0.03)\end{array}$ & $\begin{array}{l}25.15 \\
( \pm 2.26)\end{array}$ & $\begin{array}{l}16.78 \\
( \pm 0.58)\end{array}$ & $\begin{array}{l}13.45 \\
( \pm 0.25)\end{array}$ & $\begin{array}{l}7.39 \\
( \pm 0.14)\end{array}$ & $\begin{array}{l}37.62 \\
( \pm 0.97)\end{array}$ & $\begin{array}{l}183.29 \\
( \pm 12.50)\end{array}$ \\
\hline 10 & $\begin{array}{l}57.31 \\
( \pm 2.57)\end{array}$ & $\begin{array}{l}29.52 \\
( \pm 0.08)\end{array}$ & $\begin{array}{l}26.89 \\
( \pm 0.67)\end{array}$ & $\begin{array}{l}113.71 \\
( \pm 3.32)\end{array}$ & $\begin{array}{l}12.82 \\
( \pm 5.36)\end{array}$ & $\begin{array}{l}9.07 \\
( \pm 0.16)\end{array}$ & $\begin{array}{l}5.22 \\
( \pm 0.50)\end{array}$ & $\begin{array}{l}27.11 \\
( \pm 0.14)\end{array}$ & $\begin{array}{l}16.84 \\
( \pm 0.60)\end{array}$ & $\begin{array}{l}13.52 \\
( \pm 0.10)\end{array}$ & $\begin{array}{l}7.20 \\
( \pm 0.89)\end{array}$ & $\begin{array}{l}37.56 \\
( \pm 1.59)\end{array}$ & $\begin{array}{l}178.38 \\
( \pm 5.05)\end{array}$ \\
\hline 11 & $\begin{array}{l}61.88 \\
( \pm 2.12)\end{array}$ & $\begin{array}{l}31.39 \\
( \pm 1.51)\end{array}$ & $\begin{array}{l}26.81 \\
( \pm 1.84)\end{array}$ & $\begin{array}{l}120.07 \\
( \pm 5.48)\end{array}$ & $\begin{array}{l}12.81 \\
( \pm 5.36)\end{array}$ & $\begin{array}{l}9.31 \\
( \pm 0.33)\end{array}$ & $\begin{array}{l}5.29 \\
( \pm 0.17)\end{array}$ & $\begin{array}{l}27.41 \\
( \pm 0.97)\end{array}$ & $\begin{array}{l}17.55 \\
( \pm 0.56)\end{array}$ & $\begin{array}{l}13.86 \\
( \pm 0.27)\end{array}$ & $\begin{array}{l}12.05 \\
( \pm 7.22)\end{array}$ & $\begin{array}{l}43.46 \\
( \pm 6.39)\end{array}$ & $\begin{array}{l}190.95 \\
( \pm 0.06)\end{array}$ \\
\hline
\end{tabular}

a Total of malonyl glucosides expressed as the sum of the conjugates malonyl daidzin, malonyl genistin and malonyl glycitin.

b Total of $\beta$-glucosides expressed as the sum of the conjugates daidzin, genistin and glycitin.

c Total of aglycones expressed as the sum of the daidzein, genistein and glycitein.

resulting from the concentration process, and to fouling. Both phenomena commonly occur in membrane separation processes (Liikanen, Yli-Kuivila, \& Laukkanen, 2002; Suárez, Lobo, Alvarez, Riera, \& Álvarez, 2009; Van Der Bruggen, Mänttäri, \& Nyström, 2008; Warczok, Ferrando, López, \& Güell, 2004).

The average J value during NF was approximately $12.4 \mathrm{~L} \mathrm{~h}^{-1} \mathrm{~m}^{-2}$. These results are similar to those obtained by Díaz-Reinoso, Moure, Domínguez, and Parajó (2009) for an aqueous extract of distilled fermented grape pomace, and by Luo, Ding, Chen, and Wan (2009) on removing the salt from soy sauce. These authors used NF and the average fluxes were from 10 to $70 \mathrm{~L} \mathrm{~h}^{-1} \mathrm{~m}^{-2}$ and $6.64 \mathrm{~L} \mathrm{~h}^{-1} \mathrm{~m}^{-2}$, respectively. Although distilled fermented grape pomace, soy sauce, and soybeans are quite different products, it is possible to compare the results because of the similarities between the concentration processes. However, in the present study a pressure of 7 bar is appropriate, since it allows the process to be carried out within an appropriate length of time, thus resulting in lower energy consumption due to the low pressure used (Mello et al., 2010). Moreover, some studies report that shorter processing times are ideal to maintain the isoflavone content (Alothman, Bhat, \& Karim, 2009; Chien et al., 2005; Nufer et al., 2009; Rostagno, Palma, \& Barroso, 2005; Shimoni, 2009; Wang \& Murphy, 1996).

\subsection{Isoflavone contents}

The isoflavone contents in the DSF, aqueous extract of DSF, and concentrate samples are shown in Table 2.

Of the isomers present in the DSF, malonyl glucoside conjugates were predominant, representing $58 \%$ of the total isoflavones. Coward, Smith, Kirk, and Barnes (1998) also detected greater concentrations of these conjugates in soybeans and in untoasted soy flours. These authors noted that processes such as grinding and oil extraction at ambient temperature do not modify the content or the profile of this type of isoflavone. Similarly, Góes-Favoni et al. (2004) reported 59\% malonyl glucoside content in different types of whole soybean meal. These authors also noted malonyl genistin contents (35\%) similar to those obtained with DSF (33\%). Góes-Favoni (2002) obtained the same isoflavone profile for whole soybean meal, where the com- pounds malonyl and $\beta$-glucosides were predominant. However, the DSF produced showed a decrease in the malonyl conjugates and an increase in the $\beta$-glucoside conjugates, while the $\beta$-glucosides in the DSF represented approximately $40 \%$ of the total isoflavone content. Lower contents (around 34\%) were detected by Yu, Liu, Qiu, and Wang (2007) in defatted soy flour. In the present study, the malonyl glucoside and $\beta$-glucoside conjugates represented around $98 \%$ of total isoflavones, which is in agreement with the work performed by Murphy, Barua, and Hauck (2002). These authors tested different solvents for the extraction of isoflavones from soy flour and noted that these conjugates represented on average $90 \%$ of the total isoflavones.

No acetyl conjugates were detected in the DSF. According to Jung, Murphy, and Sala (2008), the formation of these isomers occurs only when the soybean or soybean products undergo drying at high temperatures, as in the toasting process for instance. The aglycones in the DSF represented $1.8 \%$ of the total isoflavone content, which is similar to levels detected by Wang and Murphy (1996) in fresh soybeans and in untoasted flours, where the content of these compounds were between 1 and $3 \%$.

The content of total isoflavones present in the aqueous DSF extract was similar to that noted by Góes-Favoni et al. (2004), who investigated two hydrosoluble extracts and detected isoflavone contents of 1800 and $1230 \mu \mathrm{g} \mathrm{g}^{-1}$, respectively. In the case of the DSF, the predominant isomers were the malonyl glucosides. However, this result was in contrast to that obtained by Coward et al. (1998), who detected the $\beta$-glucosides as the main isomers in hydrosoluble soybean extracts.

Table 4

Analyses of variance of the values of $\beta$-glucosides in the concentrate after thermal treatments.

\begin{tabular}{llllrl}
\hline Source & Sum of squares & DF & Mean square & F value & $p$ value \\
\hline (1) Temperature (L) & 0.00 & 1 & 0.00 & 355.32 & 0.00 \\
Temperature (Q) & 0.00 & 1 & 0.00 & 4.02 & 0.10 \\
(2) Time (L) & 0.00 & 1 & 0.00 & 122.08 & 0.00 \\
Time (Q) & 0.00 & 1 & 0.00 & 0.09 & 0.76 \\
$1(\mathrm{~L}) \times 2(\mathrm{~L})$ & 0.00 & 1 & 0.00 & 28.67 & 0.00 \\
\hline
\end{tabular}

$\mathrm{L}=$ linear effect; $\mathrm{Q}=$ quadratic effect; values significantly different $(p<0.05)$. 
Table 5

Analysis of variance of the values of malonyl glucosides in the concentrate after thermal treatments.

\begin{tabular}{llllrl}
\hline Source & Sum of squares & DF & Mean square & F value & $p$ value \\
\hline (1) Temperature (L) & 0.00 & 1 & 0.00 & 16.23 & 0.01 \\
Temperature (Q) & 0.00 & 1 & 0.00 & 8.20 & 0.03 \\
(2) Time (L) & 0.00 & 1 & 0.00 & 6.21 & 0.05 \\
Time (Q) & 0.00 & 1 & 0.00 & 0.10 & 0.76 \\
$1(\mathrm{~L}) \times 2(\mathrm{~L})$ & 0.00 & 1 & 0.00 & 5.15 & 0.07 \\
\hline
\end{tabular}

$\mathrm{L}=$ linear effect; $\mathrm{Q}=$ quadratic effect; values significantly different $(p<0.05)$.

According to Huang et al. (2006), such differences could result from the type of thermal treatment, such as pasteurization or sterilization, because the moist heat applied in the processing stages leads to the de-esterification of malonyl conjugates and the formation of $\beta$-glucosides. Moreover, the aglycone contents detected in the aqueous DSF extract obtained in the present study were higher than those observed by Góes-Favoni et al. (2004) in hydrosoluble soybean extract. This could be attributed to the cultivar used and to the hydrothermal treatment $\left(50^{\circ} \mathrm{C}\right)$ performed. Matsuura and Obata (1993) and Araújo, Carlos, and Sedyama (1997) state that a temperature of $50{ }^{\circ} \mathrm{C}$ is ideal for $\beta$-glucosidase activity in aqueous extracts and leads to the formation of aglycones. This result is consistent with the findings of Chien et al. (2005), who verified that the conversion of these isomers is attributable to the thermal treatment used. In the aqueous DSF extract, aglycones corresponded to $30 \%$ of the total isoflavone content, which is similar to the results obtained by Xu et al. (2004), who detected aglycone contents of around $34 \%$ of total isoflavones in the liquid residue from soybean extract production. Ribeiro et al. (2007) state that higher contents of aglycones provide greater health benefits to consumers of soybean products because, according to Esteves and Monteiro (2001), PascualTeresa et al. (2006), Cederroth and Nef (2009) and Levis, Strickman-

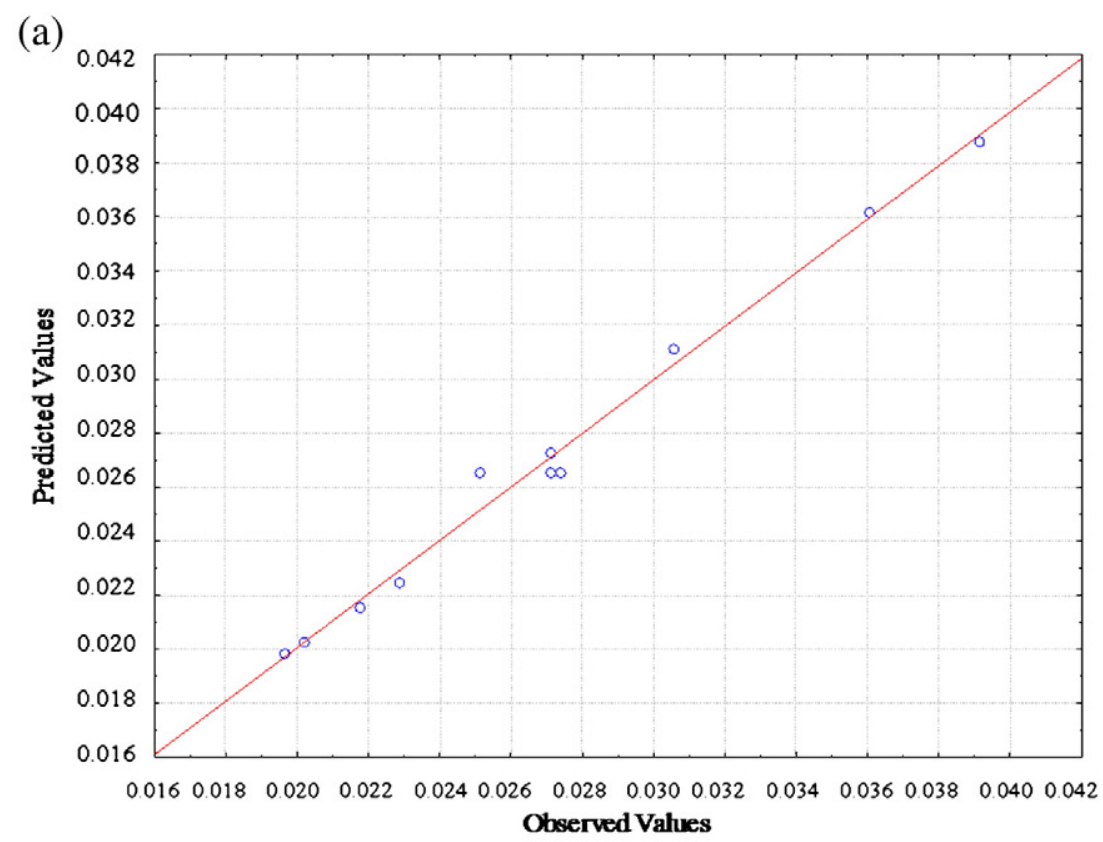

(b)

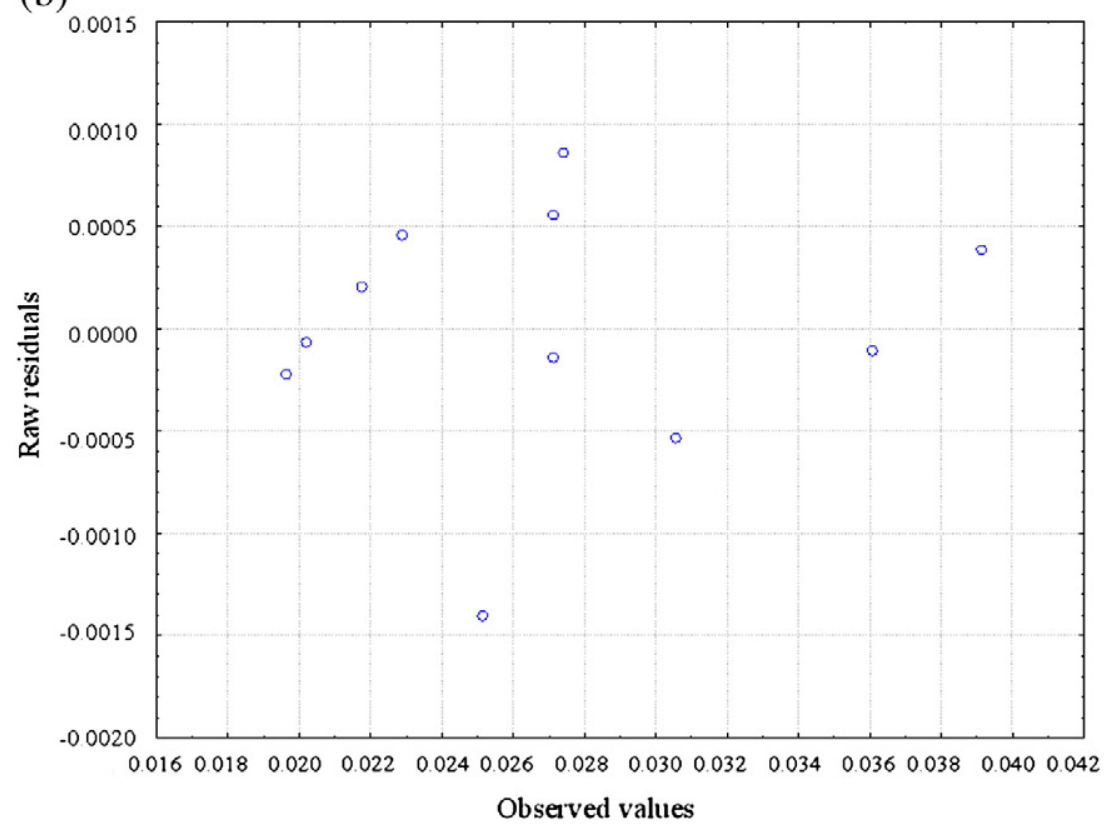

Fig. 2. (a) Plot of the predicted versus observed values of $\beta$-glucosides and (b) plot of residual versus observed values of $\beta$-glucosides in the concentrate samples. 
Stein, Doerge, and Krischer (2010), aglycones are directly absorbed in the gastrointestinal tract and therefore they show greater bioactivity than the conjugated forms. In relation to the aglycone content in the aqueous DSF extract, the profile noted in the present study was the same as that reported by Huang et al. (2006) for hydrosoluble soybean extract.

After the NF of the aqueous DSF extract, there was an increase of $42 \%$ $(p<0.05)$ in the total isoflavone content in the concentrate. However, this increase was not proportional to the VRF used (VRF $=4$ ) which, according to Wang and Murphy (1996), may be related to the association of isoflavones with soybean proteins, thus resulting in a reduction in the $\mathrm{J}$ value.

When compared with the aqueous DSF extract, the glucoside conjugate contents were higher $(p<0.05)$ in the concentrate whereas the aglycone contents in the aqueous DSF extract and in the concentrate did not differ significantly $(p>0.05)$. Considering a membrane cut-off between 150 and $300 \mathrm{~g} \mathrm{~mol}^{-1}$, these variations can be explained through the difference in the molar masses, as defined by Nurmi, Mazur, Heinomen, Hokkonen, and Adlercreutz (2002), of the glucoside conjugates (between 400 and $600 \mathrm{~g} \mathrm{~mol}^{-1}$ ) and aglycones (between 200 and $300 \mathrm{~g} \mathrm{~mol}^{-1}$ ).

\subsection{Thermal treatments of the concentrate}

The effects of the combinations between the variables temperature and time on the profile and the content of isoflavones in the concentrate were investigated and the results obtained in the 11 assays are shown in Table 3 . Among the four types of isoflavones, $\beta$-glucosides were linearly influenced $(p<0.05)$ by the variables temperature and time within the studied ranges and also an effect of the interaction between these variables was observed $(p<0.05)$. Temperature had a greater effect on the $\beta$-glucosides content (Table 4). According to Rostagno et al. (2005), temperature is the main factor which influences the stability of isoflavones during food processing. The malonyl glucosides were influenced $(p<0.05)$ only by temperature, showing a linear and quadratic effect on the response variable (Table 5). In the case of the malonyl glucosides content temperature had the greatest effect and there was no effect related to the processing time. However, the content of these compounds decreased with an increase in temperature. The effect of temperature on malonyl conjugates was also noted by Murphy et al. (2002) using a hydrosoluble soybean extract and a temperature of $80{ }^{\circ} \mathrm{C}$ for $3 \mathrm{~h}$. Barnes, Kirk, and Coward (1994), Jackson et al. (2002) and Kao, Lu, Hsieh, and Chen (2004) observed that the conversion of malonyl conjugates into $\beta$-glucosides was dependent on the factors' time and temperature. The results (Table 3) show that at higher temperatures there was a decrease in the malonyl glucosides and an increase in $\beta$-glucosides. According to Mathias, Ismail, Corvalan, and Hayes (2006), malonyl glucosides are the most thermally unstable isomers and they are converted into $\beta$-glucosides when submitted to high temperatures.

From the results obtained in this study it was possible to develop a predictive model for the $\beta$-glucoside content. A graphic indication of the quality of the model can be seen in Fig. $2 a$ and $b$. The plot of the predicted versus the observed values for $\beta$-glucosides in the concentrate samples shows a linear behavior with a correlation coefficient of 0.95 (Fig. 2a). The plot of the residuals versus the observed values (Fig. $2 \mathrm{~b}$ ) shows that the assumption of randomness of the residuals was satisfied.

The model developed for the $\beta$-glucoside content ( $\mathrm{Y}$ ) is represented through the following equation:

$Y=0.027+0.0058 X_{1}+0.0034 X_{2}+0.0023 X_{1} X_{2}$

where $X_{1}$ is the temperature and $X_{2}$ is the time of the thermal treatment of the concentrate.

Fig. 3 shows the response surface developed through regression of the model obtained, in which there is a non-proportional interaction

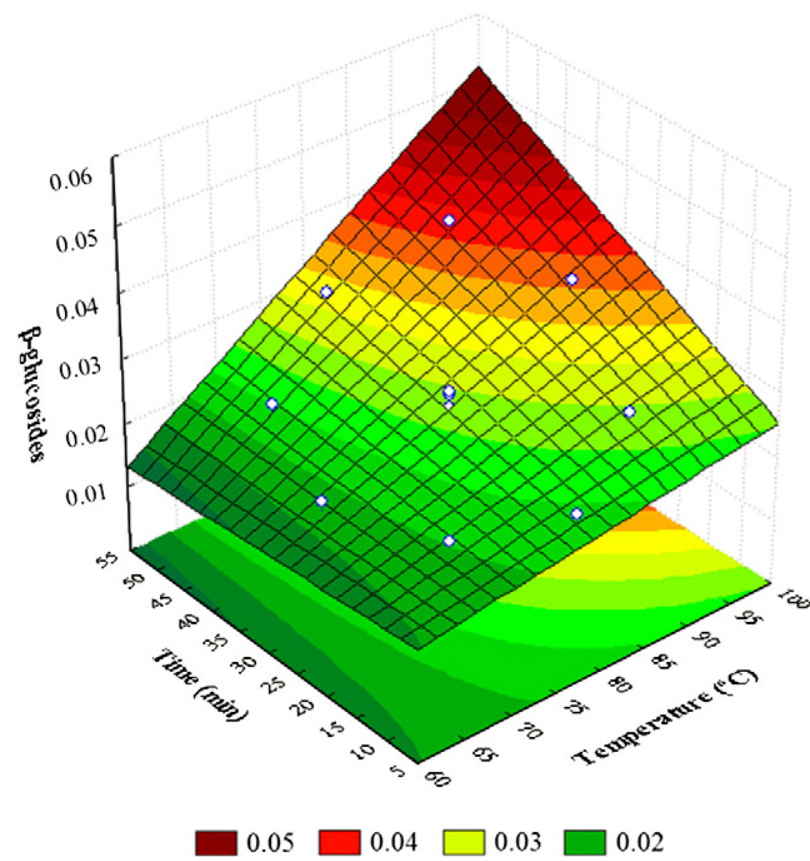

Fig. 3. Response surface plot for the $\beta$-glucosides as a function of temperature $\left({ }^{\circ} \mathrm{C}\right.$ ) and time (minutes) of thermal treatment of concentrate.

between the variables' time and temperature. Therefore, any of the time and temperature values within the ranges studied can be used in the thermal treatment of the concentrate because the $\beta$-glucoside content remains constant. Also, in relation to $\beta$-glucosides, it is stated in the literature (Grün et al., 2001; Kao et al., 2004) that there is no standard behavior in relation to thermal treatment since the type of food (matrix difference) influences the conversion of this conjugate.

After the thermal treatments, no acetyl glucoside conjugates were detected in the concentrate, in the DSF, or in the aqueous DSF extract. According to Barnes et al. (1998) and Kao et al. (2004), the formation of acetyl conjugates varies according to the manner in which the soybean foods are processed, being mainly associated with the moisture content and heat of thermal treatments.

In relation to aglycones, the variables analyzed did not influence $(p>0.05)$ these contents in the thermally treated concentrate (Table 6). A similar result was obtained by Kao et al. (2004) after applying thermal treatments to a hydrosoluble soybean extract. However, Góes-Favoni et al. (2004) and Huang et al. (2006) noted a reduction in these isomers on applying thermal treatments similar to those used in the concentrate of the aqueous DSF extract. This difference in behavior could be due to the thermal treatment $\left(50{ }^{\circ} \mathrm{C}\right.$ for $15 \mathrm{~h}$ ) previously applied to the aqueous DSF extract, leading to the formation of aglycones through the action of the $\beta$-glycosidase enzyme. Finally, the maintenance of aglycone levels in soybean products is industrially advantageous since, according to Umphress, Murphy, Franke, Custer, and Blitz (2005) and Pascual-Teresa et al. (2006), aglycones have functional properties.

Table 6

Analysis of variance of the values of aglycones in the concentrate after thermal treatments.

\begin{tabular}{llllll}
\hline Source & Sum of squares & DF & Mean square & F value & $p$ value \\
\hline (1) Temperature (L) & 0.00 & 1 & 0.00 & 0.00 & 0.99 \\
Temperature (Q) & 0.00 & 1 & 0.00 & 3.00 & 0.14 \\
(2) Time (L) & 0.00 & 1 & 0.00 & 0.77 & 0.41 \\
Time (Q) & 0.00 & 1 & 0.00 & 0.25 & 0.63 \\
$1(\mathrm{~L}) \times 2$ (L) & 0.00 & 1 & 0.00 & 0.11 & 0.74 \\
\hline
\end{tabular}

$\mathrm{L}=$ linear effect; $\mathrm{Q}=$ quadratic effect. 
Table 7

Analysis of variance of the values of total isoflavones in the concentrate after thermal treatments.

\begin{tabular}{llllll}
\hline Source & Sum of squares & DF & Mean square & F value & $p$ value \\
\hline (1) Temperature (L) & 0.00 & 1 & 0.00 & 0.43 & 0.53 \\
Temperature (Q) & 0.00 & 1 & 0.00 & 4.25 & 0.09 \\
(2) Time (L) & 0.00 & 1 & 0.00 & 0.02 & 0.87 \\
Time (Q) & 0.00 & 1 & 0.00 & 0.25 & 0.63 \\
$1(\mathrm{~L}) \times 2(\mathrm{~L})$ & 0.00 & 1 & 0.00 & 0.43 & 0.54 \\
\hline
\end{tabular}

$\mathrm{L}=$ linear effect; $\mathrm{Q}=$ quadratic effect.

The total isoflavone content remained unchanged ( $p>0.05)$ after the thermal treatments (Table 7). Mathias et al. (2006) reported that the total isoflavone content remained constant because of the interconversions between different isomers when pasteurization temperatures are used. The same behavior was noted after thermal treatment of the concentrate in the study reported herein.

\section{Conclusions}

No acetyl glucosides were detected in the concentrate or in the extract submitted to nanofiltration. The concentration of total isoflavones, mainly glucoside conjugates, was achieved through nanofiltration. The results obtained for the isoflavone profile and content in the concentrate showed that the use of nanofiltration in the concentration of isoflavones is viable.

The effect of the thermal treatments on malonyl glucoside and $\beta$-glucoside conjugates differed. Malonyl glucosides were influenced only by temperature, while the $\beta$-glucosides were influenced by time, temperature, and the interaction between the two. The contents of aglycones and total isoflavones in the thermally treated concentrates showed no change, indicating that the thermal treatments applied did not lead to the degradation of these compounds.

\section{Acknowledgements}

The authors wish to thank the Programa de Apoio ao Plano de Reestruturação e Expansão das Universidades Federais (REUNI) for financial support; the Federal University of Santa Catarina (UFSC); and Empresa Brasileira de Pesquisa Agropecuária (EMBRAPA SOJA).

\section{References}

Adlercreutz, H., \& Mazur, W. (1997). Phyto-estrogens and Western diseases. Annals of Medicine, 29, 95-120.

Alothman, M., Bhat, R., \& Karim, A. A. (2009). Effects of radiation processing on phytochemicals and antioxidants in plant produce. Trends in Food Science $\mathcal{\sigma}^{\circ}$ Technology, 20(5), 201-212.

Araújo, J. M. A., Carlos, J. C. S., \& Sedyama, C. S. (1997). Isoflavonas em grãos de soja: importância da atividade de $\beta$-glicosidase na formação do sabor amargo e adstringente. Ciência e Tecnologia de Alimentos, 17(2), 137-141.

Barnes, S., Coward, L., Kirk, M., \& Sfakianos, J. (1998). HPLC analysis of isoflavonoids and other phenolic agents from foods and from human fluids. Proceeding of the Society for Experimental Biology and Medicine, 217, 263-273.

Barnes, S., Kirk, M., \& Coward, L. (1994). Isoflavones and their conjugates in soy foods: extraction conditions and analysis by HPLC-mass spectrometry. Journal of Agricultural and Food Chemistry, 42, 2466-2474.

Barnes, S., Prasain, J., D'Alessandro, T., Wang, C. C., Zhang, H., \& Kim, H. (2006). Soy isoflavones. In D. Heber, G. Blackburn, V. Go, \& J. Milner (Eds.), Nutritional oncology (pp. 559-571). (2nd ed.). San Diego: Elsevier.

Berhow, M. A. (2002). Modern analytical techniques for flavonoid determination. In B. S. Buslig, \& J. A. Manthey (Eds.), Flavonoids in the living cell. Advances in experimental medicine and biology, Vol. 505. (pp. 61-76) New York: Klusher Academic.

Carrão-Panizzi, M. C., Almeida, L. A., Kiihl, R. A. S., Silva, J. B., Kikuchi, A., Mandarino, J. M. G., et al. (2001). Desenvolvimento de germoplasma de soja com características adequadas para o consumo in natura e para a indústria de alimentos. Documento 104 Embrapa Soja, 191, 19-20.

Carrão-Panizzi, M. C., Favoni, S. P. G., \& Kikuchi, A. (2002). Extraction time for soybean isoflavone determination. Brazilian Archives of Biology and Technology, 45(4), 515-518.

Cassini, A. S., Tessaro, I. C., Marczak, L. D. F., \& Pertile, C. (2010). Ultrafiltration of wastewater from isolated soy protein production: a comparison of three UF membranes. Journal of Cleaner Production, 18(3), 260-265.
Cederroth, C. R., \& Nef, S. (2009). Soy, isoflavones and metabolism: A review. Molecular and Cellular Endocrinology, 304(1), 30-42.

Chang, S. K. C. (2002). Isoflavones from soybeans and soy foods. In J. Shi, G. Mazza, \& M. Lemaguer (Eds.), Functional foods: Biochemical and processing aspects (pp. 39-69). (2nd ed.). Boca Raton: CRC Press.

Chien, J. T., Hsieh, H. C., Kao, T. H., \& Chen, B. H. (2005). Kinetic model for studying the conversion and degradation of isoflavones during heating. Food Chemistry, 91, 425-434.

Coward, L, Smith, M. Kirk, M., \& Barnes, S. (1998). Chemical modification of isoflavones in soyfoods during cooking and processing. The American Journal of Clinical Nutrition, 68, 1486-1491.

Cuartas-Uribe, B., Alcaina-Miranda, M. I., Soriano-Costa, E., \& Bespia, A. (2007). Comparison of the behavior of two nanofiltration membranes for sweet whey demineralization. Journal of Dairy Science, 90, 1094-1101.

Díaz-Reinoso, B., Moure, A., Domínguez, H., \& Parajó, J. C. (2009). Ultra- and nanofiltration of aqueous extracts from distilled fermented grape pomace. Journal of Food Engineering, 91(4), 587-593.

Eisen, B., Ungar, Y., \& Shimoni, E. (2003). Stability of isoflavones in soy milk stored at elevated and ambient temperatures. Journal of Agricultural and Food Chemistry, 51, 2212-2215.

Esteves, E. A., \& Monteiro, J. B. R. (2001). Efeitos benéficos das isoflavonas de soja em doenças crônicas. Brazilian Journal of Nutrition, 14(1), 43-52.

Fukutake, M., Takahashi, M., Ishida, K., Kawakurai, H., Sugimura, T., \& Wakabayashi, K. (1996). Quantification of genistein and genistin in soybeans and soybean products. Food and Chemical Toxicology, 34, 457-461.

Genovese, M. I., Barbosa, A. C. L., Pinto, M. S., \& Lajolo, F. M. (2007). Commercial soy protein ingredients as isoflavones sources for functional foods. Plant Foods for Human Nutrition, 62(2), 53-58.

Góes-Favoni, S. (2002). Desenvolvimento de Farinha de Soja [Glycine max (L.) Merrill] com Maior Teor de Genisteína. Msc. Thesis. Universidade Estadual de Londrina.

Góes-Favoni, S., Beléia, A. D. P., Carrão-Panizzi, M. C., \& Mandarino, J. M. G. (2004). Isoflavonas em produtos comerciais de soja. Ciência e Tecnologia de Alimentos, 24(4), 582-586.

Góes-Favoni, S., Carrão-Panizzi, M. C., \& Beléia, A. D. P. (2010). Changes of isoflavone in soybean cotyledons soaked in different volumes of water. Food Chemistry, 119, 1605-1612.

Grün, I. U., Adhikari, K., Li, C., Li, Y., Lin, B., Zhang, J., et al. (2001). Changes in the profile of genistein, daidzein, and their conjugates during thermal processing of tofu. Journal of Agricultural and Food Chemistry, 4(6), 2839-2843.

Habert, A. C., Borges, C. P., \& Nóbrega, R. (2006). Processos de separação com membranas. Rio de Janeiro: E-papers Serviços Editoriais Ltda.

Hodúr, C., Kertész, S. Z., Beszédes, S., László, Z. S., \& Szabó, G. (2009). Concentration of marc extracts by membrane techniques. Desalination, 241, 265-271.

Huang, H., Liang, H., \& Kwok, K. C. (2006). Effect of thermal processing on genistein, daidzein and glycitein content in soymilk. Journal of the Science of Food and Agriculture, 86, 1110-1114.

Jackson, C. J. C., Dini, J. P., Lavandier, C., Rupasinghe, H. P. V., Faulkner, H., Poysa, V., et al. (2002). Effects of processing on the content and composition of isoflavones during manufacturing of soy beverage and tofu. Process Biochemistry, 37(10), 1117-1123.

Jung, S., Murphy, P. A., \& Sala, I. (2008). Isoflavones profile of soymilk as affected by high-pressure treatments of soymilk and soybeans. Food Chemistry, 111, 592-598.

Kao, T. H., Lu, Y. F., Hsieh, H. C., \& Chen, B. H. (2004). Stability of isoflavone glucosides during processing of soymilk and tofu. Food Research International, 37(9), 891-900.

Lee, S. W., \& Lee, J. H. (2009). Effects of oven-drying, roasting, and explosive puffing process on isoflavone distributions in soybeans. Food Chemistry, 112, 316-320.

Levis, S., Strickman-Stein, N., Doerge, D. R., \& Krischer, J. (2010). Design and baseline characteristics of the soy phytoestrogens as replacement estrogen (SPARE) study A clinical trial of the effects of soy isoflavones in menopausal women. Contemporary Clinical Trials, 31(4), 293-302.

Liikanen, R., Yli-Kuivila, J., \& Laukkanen, R. (2002). Efficiency of various chemical cleanings for nanofiltration membrane fouled by conventionally-treated surface water. Journal of Membrane Science, 195(2), 265-276.

Luo, J., Ding, L., Chen, X., \& Wan, Y. (2009). Desalination of soy sauce by nanofiltration. Separation and Purification Technology, 66(3), 429-437.

Mathias, K., Ismail, B., Corvalan, C. M., \& Hayes, K. D. (2006). Heat and pH effects on the conjugated forms of genistin and daidzin isoflavones. Journal of Agricultural and Food Chemistry, 54(20), 7495-7502.

Matsuura, M., \& Obata, A. (1993). $\beta$-glucosidases from soybeans hydrolyse daidzin and genistin. Journal of Food Science, 58(1), 144-147.

Mello, B. C. B. S., Petrus, J. C. C., \& Hubinger, M. D. (2010). Concentration of flavonoids and phenolic compounds in aqueous and ethanolic propolis extracts through nanofiltration. Journal of Food Engineering, 96(4), 533-539.

Murphy, P. A., Barua, K., \& Hauck, C. C. (2002). Solvent extraction selection in the determination of isoflavonas in soy foods. Journal of Chromatography. B, 777, 129-138.

Noordman, T. R., Kooiker, K., Bel, W., Dekker, M., \& Wesselingh, J. A. (2003). Concentration of aqueous extracts of defatted soy flour by ultrafiltration: Effect of suspended particles on the filtration flux. Journal of Food Engineering, 58(2), 135-141.

Nufer, K. R., Ismail, B., \& Hayes, K. D. (2009). The effects of processing and extraction conditions on content, profile, and stability of isoflavones in a soymilk system. Journal of Agricultural and Food Chemistry, 57(4), 1213-1218.

Nurmi, T., Mazur, W., Heinomen, S., Hokkonen, J., \& Adlercreutz, H. (2002). Isoflavone content of the soy based supplements. Journal of Pharmaceutical and Biomedical Analysis, 28, 1-11.

Pascual-Teresa, S., Hallund, T. J., Talbot, D., Schroot, J., Willians, C. M., Bugel, S., et al. (2006). Absorption of isoflavones in humans: Effects of food matrix and processing. The Journal of Nutritional Biochemistry, 17, 257-264. 
Ranilla, L. G., Genovese, M. I., \& Lajolo, F. M. (2009). Isoflavones and antioxidant capacity of Peruvian and Brazilian lupin cultivars. Journal of Food Composition and Analysis, 22(5), 397-404.

Ríaz, M. N. (1999). Soybeans as functional foods. Cereal Foods World, 44(2), 88-92.

Ribeiro, M. L. L., Mandarino, J. M. G., Carrão-Panizzi, M. C., Oliveira, M. C. N., Campo, C. B. H., Nepomuceno, A. L., et al. (2007). Isoflavone content and b-glucosidase activity in soybean cultivars of different maturity groups. Journal of Food Composition and Analysis, 20(1), 19-24.

Rostagno, M. A., Palma, M., \& Barroso, C. G. (2005). Short-term stability of soy isoflavones extracts: Sample conservation aspects. Food Chemistry, 93, 557-564.

Saboya, L. V., \& Maubois, J. L. (2000). Current developments of microfiltration technology in the dairy industry. Lait, 80, 541-553.

Shimoni, E. (2009). Stability and shelf life of bioactive compounds during food processing and storage: soy isoflavones. Journal of Food Science, 69(6), 160-166.

Suárez, E., Lobo, A., Alvarez, S., Riera, F. A., \& Álvarez, R. (2009). Demineralization of whey and milk ultrafiltration permeate by means of nanofiltration. Desalination, $241,272-280$.

Sutil, G. A., Mandarino, J. M., Laurindo, J. B., Benassi, V., Góes-Favoni, \& Petrus, J. C. C. (2008). Effect of hidorthermal treatment and $\mathrm{pH}$ on the formation of aglycones em soybean. European Food Research and Technology, 227(6), 1729-1731.
Toda, T., Sakamoto, A., Takayanagi, T., \& Yokotsuka, K. (2000). Changes in isoflavone compositions of soybean foods during cooking process. Food Science and Technology Research, 6(4), 314-319.

Umphress, S. T., Murphy, S. P., Franke, A. A., Custer, L. J., \& Blitz, C. L. (2005). Isoflavone content of foods with soy additives. Journal of Food Composition and Analysis, 18(6), 533-550.

Van Der Bruggen, B., Mänttäri, M., \& Nyström, M. (2008). Drawbacks of applying nanofiltration and how to avoid them: A review. Separation and Purification Technology, 63(2), 251-263.

Wang, H., \& Murphy, P. (1994). Isoflavone content in commercial soybean foods. Journal of Agricultural and Food Chemistry, 42(8), 1666-1673.

Wang, H. -J., \& Murphy, P. A. (1996). Mass balance study of isoflavones during soybean processing. Journal of Agricultural and Food Chemistry, 44, 2377-2383.

Warczok, J., Ferrando, M., López, F., \& Güell, C. (2004). Concentration of apple and pear juices by nanofiltration at low pressures. Journal of Food Engineering, 63(1), 63-70.

Xu, L. Lamb, K., Layton, L, \& Kumar, A. (2004). A membrane-based process for recovering isoflavones from a waste stream of soy processing. Food Research International, 37(9), 867-874.

Yu, J., Liu, Y. F., Qiu, A. Y., \& Wang, X. G. (2007). Preparation of isoflavones enriched soy protein isolate from defatted soy hypocotyls by supercritical $\mathrm{CO}_{2}$. LWT - Food Science and Technology, 40, 800-806. 